\title{
A QUALITATIVE STUDY REVEALING THE RELATIONSHIP BETWEEN CULTURAL INDICATORS AND ATTITUDES TOWARD THE ADS Emine Sahin*
}

\begin{abstract}
The companies, in International markets, are required to examine the attitudes and the behaviours to recognize the consumer to be able to make their products preferable under constantly growing competitive conditions. Therefore, it is of great importance to know cultural values of the customers in the country's where global brands compete and to shape ads which is one of the marketing communication tools in this direction. In this respect, knowing the cultural similarities or differences of the countries where the ads are used (such as that country's religion, language, norms and cultural values) gains importance. The consumer attitudes towards the ads change in accordance with their cultural similarities or dissimilarities and this attitude change determines the tendency of shopping. According to Geert Hofstede, social anthropologist who analyzes the cultural levels and the relationships among them the basic elements of the culture consists of symbols, heroes, rituals and values underlying them. Thorough symbols, a number of cultural values are conveyed to ads. The problem of this study which was carried out in order to determine attitude change towards the ads including cultural differences is "Is there a difference in the attitudes towards the ads including different cultural symbols? How it is distributed according to gender differences?" In this study, a qualitative research method was applied and interviewed with 20 test subject. 20 students studying in one of the universities in Turkey were selected with formal sampling, they were asked questions, and it was tried to determine the difference between the ad of Doğuş Çay-a tea brand which uses the symbols and local accent of Black sea region in Turkey in its ads- and the ad of Lipton which is an international British tea brand. At the end of the study, it was found out that sample's the attitude was positive towards ad of Doğuş Çay, not Lipton.
\end{abstract}

Keywords: Attitudes; Cultural Values; Hofstede; Different Cultural Symbols

\footnotetext{
* Corresponding author: Emine Sahin, Research assistant at the Gumushane University and PhD
} Candidate, Turkey; e-mail: esahin@ gumushane.edu.tr 


\section{INTRODUCTION}

Foreign companies started to emerge in Turkey as well with disappearance of national boundaries after worldwide developments in marketing in 1980s. Companies have to know consumers and analyse their attitudes and behaviours to come to a place in which they can be known and preferred in international markets. In this respect, knowing cultural values of consumers in the target country's market and using advertisements gain importance. Cultural differences and factors such as religion, language and cultural values of the countries in which advertisements are published become important. On the other hand, Turkish companies entered into competition with foreign companies and started similar works to protect their place both in Turkish market and in the world market. Advertisement messages used to increase brand awareness must be parallel with values of the target country. Advertisement strategies are defined accordingly. Basic method to put forward Turkish identity is created by benefiting factors reflecting Turkish culture. In this respect, values which are belong to Turkish culture, language, life style, traditions and religious practices gain importance.

Factors which shouldn't be forgotten in international companies such as country's economic situation, target audiences' demographic and socio-cultural situation influence advertisers. Also, messages should be arranged according to these factors. Perhaps, the most important variable among these is culture. While culture, which have been defined countless, is defined by Turkish communicator Mutlu as "everything reflecting to codes, dressing styles, lifestyle and beliefs of a society (Mutlu, 2008:194), it is defined as purification of 
civilization and mind by Hofstede and he points out that this purification can be realized by literature, art and education (Hofstede, 1997:5).

Cultural differences are important factors for global advertisement's messages to be understood. Commercial films in Turkey give partially foreign and Turkish brands' demonstrations. In this respect, advertisements gain importance in cultural harmony because giving messages in advertisement based on a language and communication tools (Schütteve Ciarlante, 1998). The closer the language and the fictional scenes used in advertisement to the society, the more people understand it. Speaking the same language with the target audience, benefiting from the same sensibility and components such as names, images, behaviour patterns influence attitudes both for advertisements and companies.

Studies done on culture makes several definitions to reveal diversity of culture based on the fact that culture differs in each country. While Edward Hall defines cultural diversity according to "Information Systems Model", Hofstede explains it according to "Cultural Dimensions Model" and Kuluckhohn and Strodbeck explains it according to "Value Tendency Model" (Kartari, 2001). When Hosftede expresses cultural diversity, he claims that culture is not only different in economical and judiciary terms but also in management system. He divides countries into two groups according to their similarities and differences and he separates these two groups by criteria that he defines as cultural dimensions. 


\section{Literature Review}

Advertisement, which is a marketing tool for companies in global market, is entitled as glocal advertisement and global advertisement (Elden, Erişimtarihi: 10.08.2012). While glocal advertisements have the same messages for all the countries that the advertisement is published, global advertisements have messages including cultural differences. Also, there are national advertisements including cultural values of local company's target audiences.

When glocal or international advertisements ignore country's cultural values, they get reaction from society and in the upcoming days it can even be removed because of the fact that it does not comply with publication principles. For example, in several Arabic countries using holy symbols such as cross, Mecca and using alcohol and naked women pictures unless it is obvious that she is western is forbidden. In a recognized tea company advertisement, the actor was using his left hand and Saudi Arabian people had negative attitude for the brand because of this (Dereli, 2002:95-96). Çaykur commercial film in which, Müslüm Gürses played sparked a debate. In the days when he was struggling for life after his by-pass, this commercial film was being published frequently. This situation got a big reaction in social media (http://www.haber7.com/televizyon/haber/999572muslum-gursesin-reklami-yayindan-kaldirildi). After claims that the company takes advantage of his fans, the commercial film is removed.

Culture defining brands' advertisement and message strategies is the most extensive subject of social sciences and a fact that is defined and explained countless. Every researcher studying in an area 
of culture explains it based either on ethnic or humane or social classes (Lull, 2001:97).

Culture is transferring symbols, behavioural patterns, social lows, moral principles and religious views belong to the society to future generations by individuals. Society's values explain experiences in addition to learned behaviours (Giddens, 2010:30).

Anthropologist Malinowski makes a definition of culture which is in the anthropology's area of investigation in this way; Culture is a basic complement which is composed of usage and consumption items, groups' rights and duties, people's thoughts, abilities, beliefs and habits (Malinowski,cited byYaylagülveKorkmaz, 2008:188). Individuals' thoughts and beliefs lead their habits and these habits become their lifestyles. In culture's definition which Hofstede summarizes as "unwritten rules of a social play" individual's complying with general structure of his society (Giddens, 2010:35). Unwritten norms are valid for general individuals and force them to obey these rules. These rules can vary not only among societies but also within these societies. Therefore, Culture is a total of symbols and behavioural patterns of society's laws, moral principles, traditions and religious beliefs. It consists of concrete and moral components. Accordingly, concrete components include art, theatre, literature, music, language, dressing, architecture, food, history, climate, and geography. Moral components include ideas, behaviours, ideals, norms, values, beliefs and habits (Ügeöz, 2003:21)

While Giddens states that people attribute a meaning to objects, relations and ideas by means of symbols (Giddens, 2010:34), Hofstede likens culture to an onion and classify cultural elements as: 
symbols, heroes/leaders, rituals and values (Ügeöz, 2003:21; Soydaş, 2010:56). He based this classification on his definition. The elements that he defines as culture components come from the culture's meaning "Unwritten rules of the play". He supports that culture come in existence in four ways as symbols, heroes, rituals and values in "Cultural Onion". Each layer affects the other and demonstrates itself as a symbol in the final stage. According to Hofstede what differentiates people from other people and other societies is how they interpret and code these cultural values (Soydaş, 2010:56).

There are numerous studies about culture in multi-cultural countries such as United States of America and Canada. Graham (2005) made a research by e-mail questionnaire to find out effects of advertisements using English as a first language and Spanish as a second language on acculturation in the States which has a lot of immigrants from Mexico. It is found out that Americans of Spanish origin have positive attitude towards the advertisements in Spanish and they prefer Spanish in the advertisements. Caillat and Mullar (1996) made a research on American and British accents and found out that direct statements are more effective in commercial films using American accent and indirect statements are more effective in the ones using British accent. Moreover, Cheng and Scweitzen (1996) made a research on commercial films published in primetime in China which is not an American and a Western country and found out that while symbolic values are given more importance in the country, daily life values are given more importance in the States. Also, Han and Shavitt (1994) put forward that American and Korean advertisements have differences. Hofstede reveals that American 
advertisements include individualism and Korean ones includecollectivism. According to him while American society is individualistic, Korean society is a collective society.

Garcia (2004) in his study revealing culture's effects in fashion advertisement on Mexican immigrant students living in the States and American students found out that nation is not the only variable in cultural differences. In addition, it is revealed that while students of both nations like advertisements including reasonable sexuality, they do not like the ones including high level of sexuality.

Cultural differences play an important role in international marketing as well as in international advertisements. Therefore, there is obvious link between culture and language. Understanding culture without understanding the language spoken is impossible but language is not the only determiner. Individual manners among the values are determiners of brand choosing.

One of the values determining consumers' behaviours is attitude, but of course it is not the only one. Attitude is a tendency to react either in a negative or in a positive way to objects, beliefs and environment that people have (OdabaşıveBarış, 2010:157). There are numerous attitude studies in the field of social sciences but attitude first enter this field as an analysis tool by Thomas and Florian Znanienki's (1927) studies. They define attitude as an "individual consciousness process" (Mutlu, 2008:285).

Attitudes are determiners of behaviours. Therefore, attitude researches gain importance in the fields of communication, marketing, sociology and psychology. There are a lot of attitude 
analyses of advertisements in literature. Because attitude alteration realized by persuasion come forward as behaviour alteration.

The most cited study in this field is Bauer and Greyer's study. These researchers contribute to the field by the first study revealing people's attitudes for advertisements and they used in-depth interview method (İspir and Suher, 2009:7). The study reveals that there are many positive attitudes to advertisements but there is also respondents' doubt in advertisements' persuasiveness. Also, Alwitt's and Praphaker's study (1992) and Andrew's study (1989) put forward that persuasiveness of advertisement messages is low (Shavittve ark.1998:8).

Lutz (1985) supports that there are five processors and there are advertisement persuasiveness, advertisement perception, attitude for advertisers, general attitude for advertising and mood (Durvasulaakt, Onay, 2013:55). However, it is seen that culture is ignored in these processors. In attitude studies, La Tour and Henthorne's study (1994) is an outstanding one as well. In China, Tai (1999) made an attitude research for sexual appeals and he found out that negative attitude was developed for the advertisements and brands using high level of sex appeal. It is observed that there is a positive attitude towards the advertisement having medium level of sex appeal.

In Turkey, Ödül (2008) made a research to analyses attitudes for Turkish and foreign advertisements. He applied a questionnaire to Turkish students. MA students say that foreign advertisements do not convince them to buy their products and they do not lean to standards 
in advertisements. Moreover, they say that they frequently encounter the concept of family unity in Turkish advertisements. They think that foreign ones do not appeal to every education level in Turkey. Undergraduate students find foreign advertisements more creative. In Şener's research (2007) related to the advertisements about sexual appeals, he made high and medium levels of attitude analyses related to the advertisements of two national brands on students. The result is that the attitude towards the brand that uses high level of sexual appeal is positive; while, the attitude is negative towards the same brand. Women's negative attitude turned out to be low level.

Bergman (2006) and Dursun (1997) deal with demographic elements in their studies done in two different countries. In his study, Bergman finds out that gender is not important in consumption behavior. Old consumers look for information about production in advertisements, and also individuals having low education level give importance to information in advertisements. In Dursun's research, it is revealed that women have more positive attitude in terms of advertisement's economical effect and men have powerful positive attitude in terms of advertisement's social effect (Onay, 2013:56-57). As it can be seen both culture and attitude studies vary. Especially, international and global companies inevitably have to take these analyses into account to remain in the market. Professor Gray and Dr. Run made a research in 2005 to benefit from it in multiculturalism and multi-ethnicity studies. They found out that Iban, Chinese and Malay societies have differences in their attitudes towards advertisements (Grey ve Run, 2005:14-18). 


\section{Problem}

Are there any differences in attitudes towards advertisements including different cultural symbols? What is the contribution of gender to attitudes?

\section{Purpose}

The purpose of study is to prove that cultural values, which constitute the last layer, are represented differently by symbols as Hofstede says and explain differences in attitudes towards two different commercial films -one of them is an advertisement of Doğuş Çay which is produced in the Eastern Black Sea Region and the other is an advertisement of international brand Doğuş Çay - .

\section{Limitations}

In addition to limitations stemming from qualitative study, this study is restricted to 20 students studying in the Department of Communication in University of Gumushane. 10 of them were born and lived in the area in which local values are symbolized and national tea company make production. Other 10 of them were born and raised in different parts of the country. 14 of the students are males and 6 of them are females. Other variables restricted the study are statements expressing cultural differences in the commercial films and gender.

\section{Research Method}

Method gains importance after literature review of the study and conception explanations is done. In-depth interview method was used in the study. Formal sample was chosen. 20 students who are 
nearly in the same ages were interviewed. Thus, age and profession factors are ignored and only the places they had lived before they came to the university became important. Interviews are carried out one-to-one in different rooms far away from the images which can affect their concentration.

Each interview was recorded and the participants were given this information beforehand. They were also told that this is voluntary and all the information was going to be secret. Therefore, false names were used instead of their real names and findings were represented in Table-1.

Table 1-Participants' features

\begin{tabular}{|c|c|c|c|c|c|c|}
\hline Participants & Nickname & Gender & Dateofbirth & Vocation & Residence & income \\
\hline 1. & Tuncay & Male & 1991 & Student & Trabzon & $800 \mathrm{tl}$ \\
\hline 2. & Abdullah & Male & 1991 & Student & Trabzon & $350 \mathrm{tl}$ \\
\hline 3. & Esra & Female & 1991 & Student & Artvin & $500 \mathrm{tl}$ \\
\hline 4. & Erdal & Male & 1991 & Student & Trabzon & $500 \mathrm{tl}$ \\
\hline 5. & Gülcan & Female & 1989 & Student & Trabzon & $300 \mathrm{tl}$ \\
\hline 6. & Sümeyye & Female & 1992 & Student & Trabzon & $350 \mathrm{tl}$ \\
\hline 7. & Murat & Male & 1992 & Student & Trabzon & $500 \mathrm{tl}$ \\
\hline 8. & Emre & Male & 1990 & Student & Trabzon & $300 \mathrm{tl}$ \\
\hline 9. & Elif & Female & 1988 & Student & Trabzon & $500 \mathrm{tl}$ \\
\hline 10. & Ayça & Female & 1992 & Student & Rize & $300 \mathrm{tl}$ \\
\hline 11. & Gözde & Female & 1990 & Student & Tokat & $280 \mathrm{tl}$ \\
\hline 12. & Halit & Male & 1992 & Student & Erzurum & $400 \mathrm{tl}$ \\
\hline 13. & Can & Male & 1990 & Student & Adana & $350 \mathrm{tl}$ \\
\hline 14. & Orhan & Male & 1990 & Student & Uşak & - \\
\hline 15. & Özkan & Male & 1991 & Student & Tokat & $400 \mathrm{tl}$ \\
\hline 16. & Ali & Male & 1991 & Student & Çorum & $600 \mathrm{tl}$ \\
\hline 17. & Yavuz & Male & 1992 & Student & İstanbul & $400 \mathrm{tl}$ \\
\hline 18. & Ahmet & Male & 1992 & Student & Tokat & $300 \mathrm{tl}$ \\
\hline 19. & Ercan & Male & 1988 & Student & Iğdır & $800 \mathrm{tl}$ \\
\hline 20. & Mahmut & Male & 1993 & Student & Gümüşhane & $220 \mathrm{tl}$ \\
\hline
\end{tabular}


Before interview, two advertisements were analyzed according to Hofstede's "Cultural Onion". Advertisements analysis as follows:

Doğuş Çay: (Figure 1) In the advertisement of national brand Doğuş Çay, which is produced in the Eastern Black Sea Region, "yazma" a kind of scarf is used. However, "yazma" which belongs to the Black Sea Region, is a scarf that women use traditionally rather than religiously. Also, actress in the commercial film is wearing a "peştemal". This is a cloth that is used only in the Black Sea Region. "Peştemal" is not worn in daily life; it is worn in weddings in rural parts of the region. On the other hand, the film is recorded in a tea garden. The actress is speaking in a Black Sea accent. She is using local statements like "daldurma, yerinkulavardur, ha buçay”.

Lipton Çay: (Figure 2) Lipton took its place in Turkish market in 1986 with its factory in Pazar, in Rize after tea sector's being privatized. Contrary to DoğuşÇay's commercial films, a woman blonde with short hair and having European appearance (probably, her role is a business woman) plays in Lipton's commercial films. Even though, it is emphasized that the production place of tea is the Black Sea Region, the place where the film is recorded is a kitchen having the most developed kitchen tools. Moreover, voice-over is speaking in İstanbul accent.

As it can be seen, both films have differences in performers, accent and the place that they are recorded. Both of the brands are produced in the Eastern Black Sea Region and have the same taste but they are presented in different ways.

\section{Findings}


While attitudes of the participants towards the advertisements were expected "positive, negative and indecisive", their attitudes were only positive or negative. Positive attitude means "approving the commercial film, enjoying it and finding no missing", negative attitude means "not approving it, not enjoying it, and finding some missing".

Findings consist of answers of questions regard two scales used in La Tour, Henthorne and Nataraajan's researches. The questions are such as "How do you evaluate advertisement in general terms?", "Which advertisement is a good one, which one is interesting?", "If s/he likes/doesn't like, the ways s/he likes/doesn't like", "Which advertisement/brand is closer to you in terms of culture?”.

Table 2: Attitudes of respondents to advertisement

\begin{tabular}{|c|c|c|c|}
\hline Participants & $\begin{array}{l}\text { Nickna } \\
\text { me }\end{array}$ & $\begin{array}{c}\text { Attitude towards } \\
\text { the ad of } \\
\text { DoğuşÇay }\end{array}$ & $\begin{array}{l}\text { Attitude towards the ad } \\
\text { Lipton Çay }\end{array}$ \\
\hline 1. & Tuncay & Positive & Negative \\
\hline 2. & Abdullah & Positive & Negative \\
\hline 3. & Esra & Positive & Negative \\
\hline 4. & Erdal & Positive & Negative \\
\hline 5. & Gülcan & Positive & Negative \\
\hline 6. & Sümeyye & Positive & Negative \\
\hline 7. & Murat & Positive & Negative \\
\hline 8. & Emre & Positive & Negative \\
\hline 9. & Elif & Positive & Negative \\
\hline 10. & Ayça & Positive & Negative \\
\hline 11. & Gözde & Positive & Negative \\
\hline 12. & Halit & Positive & Negative \\
\hline 13. & Can & Positive & Negative \\
\hline 14. & Orhan & Positive & Negative \\
\hline 15. & Özkan & Negative & Positive \\
\hline 16. & Ali & Positive & Negative \\
\hline 17. & Yavuz & Positive & Negative \\
\hline 18. & Ahmet & Negative & Positive \\
\hline
\end{tabular}




\begin{tabular}{|c|c|c|c|}
\hline 19. & Ercan & Positive & Negative \\
\hline 20. & Mahmut & Negative & Positive \\
\hline
\end{tabular}

As a result of in-depth interview all of 6 female respondents $(5$ of them are coming from the cities in the Eastern Black Sea Region) and 11 out of 14 male respondents like DoğuşÇay's advertisement. 3 of males (Ahmet, Özkan and Mahmut) like Lipton Çay's advertisement. Ahmet and Özkanare from Tokat and Mahmut is from a place which is far away from the Eastern Black Sea Region. The first question of the research is that whether attitudes are positive towards advertisements including local culture. The symbols and the language used in DoğuşÇay’s advertisements make respondents feel the brand closer to them. The second question of the research is that whether gender has any effects on attitudes. It is answered as no, because 6 of the females like DoğuşÇay's advertisement.

As it can be understood from the table above, only one of 14 males (he is from Trabzon), 4 of 6 females (four of them from Eastern Black Sea Region) do not like Lipton brand. In total, 4 females and 13 males like Lipton brand. The facts that 5 of the respondents have Lipton Çay in their houses and 8 of them have difficulty in remembering advertisement are among the additional information.

Abdullah, one of the participants, described DoğuşÇay as "marvellous".

He says: "It tells of our area". However, he said that he likes Lipton more as a brand.

Erdal also thinks the same: "It tells of our area. Clothes and the dialog among them and tea gardens are from our area. However, in terms of in formativeness, I prefer Lipton. 
Tuncay and Murat like the advertisement of Doğuş Çay; however, they find clothes and language exaggerated.

Emre stated that the accent of Black Sea region makes the advertisement more attractive and he likes the advertisement. However, he finds the advertisement of Lipton sufficient as it states the importance of hygiene and it is pure in terms of information content.

Elif, one of the participants from Trabzon, likes the advertisement of DoğuşÇay and she adds: "The advertisement of Lipton is chillier; the characters are European and snob. The woman from the advertisement and the environment in which she acts seem chilly to me. Whereas, DoğuşÇay, costumes, the wasp wasted tea cup and plateaus are closer to us".

Ayça also finds the advertisement of Lipton chilly and she claims: "It is more elite, I think it does not tell something that belongs to us. It does not tell about Turkey, it is like a tea of another place".

Ali, on the other hand, likes Doğuş Çay more and emphasizes the phrase of "daldurmaçay" and then says that the advertisement hits the target.

Ahmet, on the other hand, says that he likes the advertisement of Lipton more and thinks it is natural but he finds the advertisement of DoğuşÇay artificial. Ercan says: "I am on the side of localness, If Lipton came up with a local advertising campaign, it would be more successful. I look to localness; however, the one that I am satisfied when I drink is Lipton".

\section{Results}


Although evaluating attitudes towards advertisements depending on one or several variables limits the research it reveals how culture is effective on attitudes. Besides 10 people living in the Eastern Black Sea Region, other 7 (total 17) people develop positive attitudes towards the advertisement using local language, clothes and place. This inference shows that nationalism as well as localness gain importance. It is revealed by researches that attitudes influence shopping behaviours. However, as an answer of additional questions participants told that 3 of them had DoğuşÇay and 6 of them had Lipton Çay in their houses. This situation necessitates a new research centred on "Brand image" which can develop a new point of view for researches. The result is that cultural differences and cultural symbols used in advertisements is a very important factor, but it is not the only one.

\section{Figure 1}

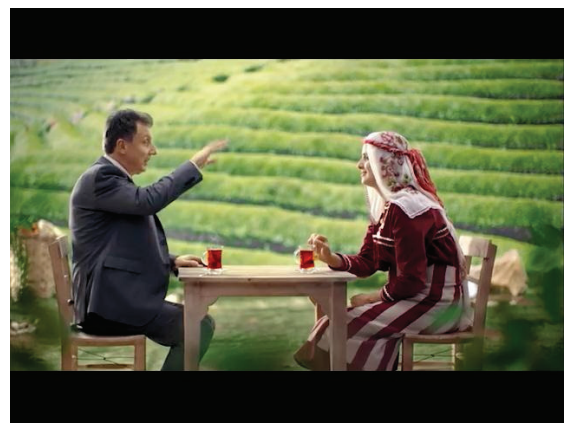




\section{Figure 2}

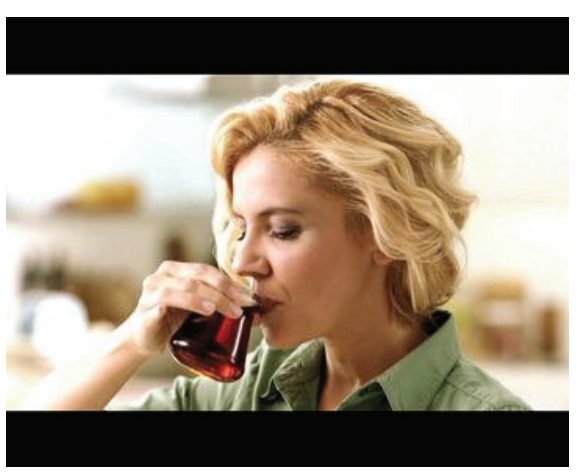

\section{References}

Barış, G. ve Odabaşı, Y. 2010. Tüketici Davranışları. MediaCat, İstanbul

Caillat, Z. ve Muller, B. 1996. "The Influence of Culture on American and British Advertising: An Exploratory Comparison of Beer Advertising." Journal of Advertising Research, 36(3), 79-87.

Cheng, H. Ve Schweitzer, J. C. 1996. "Cultural Value Reflected in Chinese and U. S Television Commercials." Journal of Advertising Research, 36(39), $27-$ 45 .

Dereli, A. 2002. Uluslar Arası Reklamlarda Farklı Kültürlerin Etkileri, Marmara Üniversitesi Sosyal Bilimler Enstitüsü, Yayınlanmamış Yüksek Lisans Tezi, İstanbul.

Elden, M. 2005. Glokal Reklam Kampanyalarında Yaratıcıllı̆ın Önemi, Bilig, S.32, ss 65-82. Available at: http://www.yesevi.edu.tr/bilig/biligTur/pdf/32/6582.pdf (10 Aralık 2012).

Garciya, E. 2004. The Effects of Cultural Values On International Advertising Effectiveness: A Study of Sex Appeals in Fashion Advertising. The University of Texas at El Paso, Unpublished Master Thesis, Texas.

Giddens, A. 2010. Sosyoloji Başlangıç Okumaları, Say yayınları, İstanbul.

Graham, K. W., 2005. Direct Mail Advertising to Hispanic. Unpublished Master's Thesis, Oklahama University, Oklahama.

Han, S. And Shavitt, S. 1994. "Persuasion and Culture: Advertising Appeals in İndividualistic and Collective Societies." Journal of Experimentalsocial Psychology. 30, 326-350.

Hofstede, G. 1997. Cultures and Organization, Software of the Mind. McGraw-Hill, New York.

21

Epiphany: Journal of Transdisciplinary Studies, Vol. 7. No. 1, (2014) ๑ Faculty of Arts and Social Sciences 
İspir, B. N, Suher, K. H. 2009."SMS Reklamlarına Yönelik Tüketici Tutumları”, Selçuk İletişim, Cilt 5, Sayı 4, (Erişim Tarihi: 12.05.2013).

Kartari, A. 2001. Farklıllklarla Yaşamak, Ürün Yayınları, Ankara.

Korkmaz, N. Ve Yaylagül L., 2008. Medya Popüler Kültür Ve İdeoloji, Dipnot Yayınları, 1. Cilt, Ankara.

Lull, J. 2001. Medya İletişim Kültür, (Çev: Güngör N.), Vadi Yayınları, Ankara.

Mutlu, E. 2008. İletişim Sözlüğü, Ayıraç Yayınları, Ankara

Onay, A. 2012. Reklamlara Yönelik Tutumlar: Nitel Bir Araştırma, e-gifder, www.e-gifder.gumushane.edu.tr., Cilt:1, Sayı:4, 51-66

Ödül, D., 2008. Uluslararası Kültürel Farklılıkların Reklamlar Üzerine yansıması ve bir Uygulama, İstanbul Üniversitesi SBE, Yüksek Lisans Tezi, İstanbul.

Run, C. Ve Grey, B., 2005. "Attitude Towards the Ad: Assessing Measurement Invariance in Cross-Ethnic Research." In Marketing in International and Cross-Cultural Environments, 14-20, 2005 (Anadolu Üniversitesi Veri Tabanından 22 Nisan'da Ulaşılmıştır.).

Schütte, H. Ve Ciarlante, D. 1998. Consumer Behaviour In Asia, New York University Press, (5 Eylül 2012).

Soydaş, A.U. 2010. Kültürlerarası İletişim: Farklı Kültürel Ortamlarda Çalışma Ve İletişim, Parşömen Yayıncılık, İstanbul.

Shavitt, S.,Lowrey, P., ve Heafney, J. 1998. "Public Attitudes Toward Advertising: More Favorable Than You Might Think", Journal of Advertising Research, July/August, 7-22.

Şener, G., 2007. "Reklamlarda Cinsel Çekicilerin İletişim Etkisi ile Ahlaki Değerlendirmesine Yönelik Tutum Araştırması", Anadolu Üniversitesi Sosyal Bilimler Enstitüsü Yüksek Lisans Tezi, www.Belgeler.com.

Tai, H. C. S., 1999. "Advertising Ethics: The Use of Sexual Appeal in Chinese advertising." Teaching Business Ethics, 3(1), 87-100

Ügeöz, P. 2003. Kültürlerarası İletişim, İstanbul Üniversitesi Yayınları, İstanbul. 